\title{
NAUTILUS BERCANGKANG RAPUH DARI TELUK TOMINI KABUPATEN PARIGI MOUTONG SULAWESI TENGAH, INDONESIA
}

\section{PAPER NAUTILUSES FROM TOMINI BAY PARIGI MOUTONG REGENCY CENTRAL SULAWESI, INDONESIA}

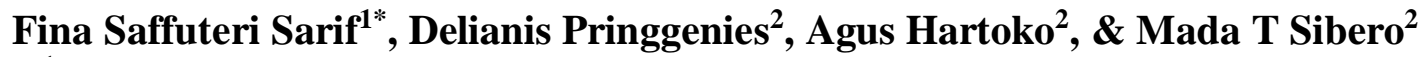 \\ ${ }^{1}$ Program Studi Manajemen Sumberdaya Pantai, Fakultas Perikanan dan Ilmu Kelautan, \\ Universitas Diponegoro, Semarang, 50275, Indonesia \\ ${ }^{2}$ Departemen Ilmu Kelautan, FPIK, Universitas Diponegoro, Semarang, 50275, Indonesia \\ *E-mail: delianispringgenies@ lecturer.undip.ac.id
}

\begin{abstract}
Paper nautiluses are classified as Cephalopoda class, Argonautidae family. The aims of this research to identification of shell morphological characters of paper Nautiluses were collected at $1,000 \mathrm{~m}$ depth. The results showed that out of all the samples successfully collected during the course of the study (March till December 2016), only 6 specimens were found at 70-80 depth, with 4 of those species are egg-laying, and the other 2 are not. From the 6 species found, 2 were Argonauta argo with average shell length of $34.05 \mathrm{~mm}$, shell width of $22.20 \mathrm{~mm}$, and average aperture width of $11.15 \mathrm{~mm}$. A. argo is known to possess 8 tentacles, 4 long and 2 short appendages. The shell color is brighter than that of A. hians, with flatter shell and two strips of keels located near each other along the dorsal and soft side, along ventral side thickens and sharpens. A. hians possess average shell length of 47.02 $\mathrm{mm}$, shell width of $33.07 \mathrm{~mm}$ and aperture width of $21.30 \mathrm{~mm}$. This species has more pronounced and blunt keels along its wide dorsal side, along lateral side the aperture widens and does not have a wing-like form. The riblines found in lateral sides are thicker and moreloose. It is concluded that 2 paper nautilus species were found in Tomini bay, Central Sulawesi, namely A. argo and A. hians.
\end{abstract}

Keywords: Argonauta argo, Argonauta hians, paper Nautilus, Tomini bay

\begin{abstract}
ABSTRAK
Nautilus bercangkang rapuh termasuk dalam kelas Cephalopoda, famili Argonautidae. Tujuan dari penelitan ini adalah untuk mengidentifikasi jenis Nautilus bercangkang rapuh yang ditemukan di perairan Teluk Tomini Kabupaten Parigi Moutong. Sampel paper Nautilus ditangkap pada kedalaman $1000 \mathrm{~m}$. Hasil penelitian memperlihatkan bahwa sampel yang berhasil dikoleksi selama bulan Maret hingga bulan Desember hanya sebanyak 6 spesimen pada kedalaman 70-80 m, dengan 4 spesimen yang bertelur dan 2 spesimen tanpa telur. Dari 6 spesimen yang ditemukan, diketahui ada 2 jenis yaitu Argonauta argo dengan rerata panjang cangkang $=34,05 \mathrm{~mm}$, lebar cangkang $=22,20 \mathrm{~mm}$ dan lebar aperture $=11,15 \mathrm{~mm}$. A. argo memiliki 8 tentakel dengan 4 tentakel panjang dan 2 pendek. Warna cangkangnya lebih cerah dari cangkang $A$. hians, cangkangnya lebih pipih dengan dua baris duri kecil yang sangat berdekatan di sepanjang sisi dorsal dan halus, sepanjang sisi ventral ujung tebal dan meruncing. Serta A. hians yang memiliki rerata panjang cangkang 47,02 mm, lebar cangkang 33,07 $\mathrm{mm}$ dan lebar aperture $21,30 \mathrm{~mm}$, memiliki duri yang lebih besar dan tumpul, di sepanjang sisi dorsal yang lebar, sepanjang sisi lateral aperture melebar dan tidak membentuk seperti sayap. Garis rusuk yang terdapat di sisi lateral lebih tebal dan renggang. Jenis Nautilus bercangkang rapuh yang ditemukan di Teluk Tomini, yaitu A. argo dan A. hians.
\end{abstract}

Kata kunci: Argonauta hians, Argonauta argo, Nautilus cangkang rapuh, Teluk Tomini

\section{PENDAHULUAN}

Teluk Tomini memiliki luas \pm 59.500 $\mathrm{km}^{2}$ yang merupakan satu-satunya teluk di dunia yang dilewati oleh garis khatulistiwa (DKP Parigi Moutong, 2013). Dalam pembagian kawasan keanekaragaman hayati, kawasan ini berada di zona Wallacea. 
Menurut sejarah, kawasan tersebut merupakan kawasan terpisah dari Benua Asia mau pun Australia sehingga teluk ini memiliki potensi sumber daya alam yang kaya dan unik. Hal tersebut juga dilengkapi dengan keanekaragaman terumbu karang dan ikanikan karang melimpah dengan spesies endemik Teluk Tomini (Wallace et al., 2000), mamalia laut, penyu serta berbagai jenis organisme lainnya (Strobbe et al., 2010). UNESCO menyebutkan teluk Tomini merupakan salah satu kekayaan dunia yang harus dilindungi karena memiliki potensi laut yang kaya dengan keindahan bawah laut dan sumber daya ikan yang berlimpah (Obie et al., 2014).

Teluk Tomini memiliki letak geografis yang spesifik dengan keberadaan biotanya yang unik dan jarang ditemukan di tempat lain, seperti Nautilus bercangkang rapuh atau lebih dikenal dengan nama paper Nautilus. Paper Nautilus atau Nautilus bercangkang rapuh adalah Cephalopoda jenis Octopus dan bukan jenis Nautilus. Berdasarkan hasil pengamatan, Nautilus bercangkang rapuh yang ditemukan di perairan teluk Tomini, walaupun kemunculannya sangat jarang, yaitu dari bulan Maret hingga November 2016 tercatat hanya ada 3 spesimen tertangkap pada kedalaman $70-80$ m (Sarif et al., 2017) artinya Natilus bercangkang rapuh adalah biota langka yang hanya ditemukan di wilayah tertentu di dunia. Berdasarkan hal tersebut, maka tujuan penelitian adalah untuk mengetahui jenis Nautilus bercangkang rapuh yang terdapat di wilayah perairan teluk Tomini Kabupaten Parigi Moutong, Sulawesi Tengah.

\section{METODE PENELITIAN}

\subsection{Sampling Nautilus Bercangkang Rapuh}

Sampel Nautilus bercangkang rapuh ditangkap menggunakan pukat cincin (purseine) dengan panjang jaring $300 \mathrm{~m}$ dan lebar $80 \mathrm{~m}$ (Figure 1) dan rumpon permukaan yang diletakkan pada kedalaman
$1000 \mathrm{~m}$ dengan ukuran $9 \mathrm{~m}$ x $9 \mathrm{~m}$ (Figure 2). Sebelumnya, Nautilus bercangkang rapuh pernah terjaring oleh nelayan saat menggunakan pukat cincin ketika menangkap ikan. Pukat cincin dipasang mengelilingi rumpon pada dini hari dan hasil tangkapan diambil pada malam berikutnya. Setelah hasil tangkapan diambil, jaring dipasang kembali pada posisi semula. Penelitian dilakukan pada bulan Maret hingga Desember 2016 dengan metode Purposive sampling.

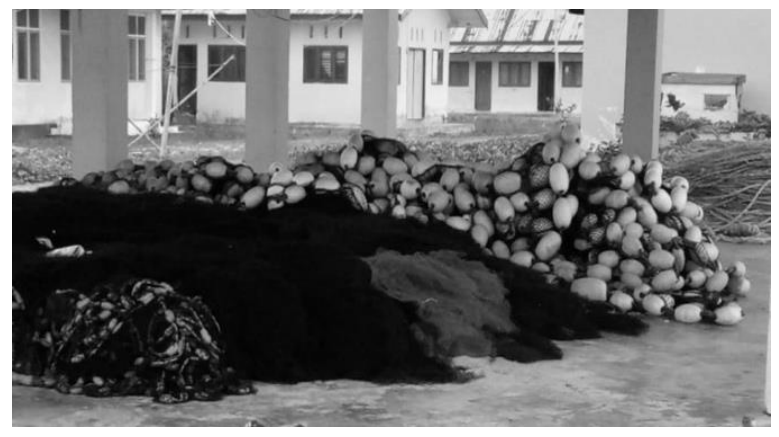

\section{Figure 1. The Purse Seine used to capture paper Nautilus.}

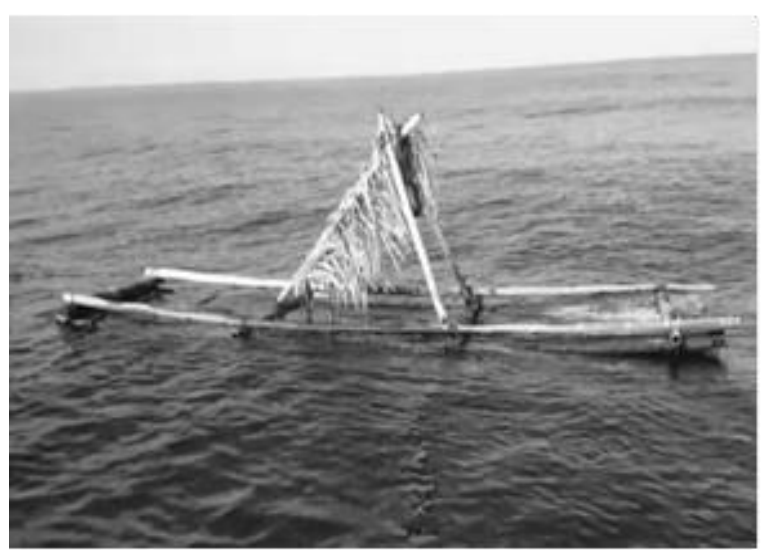

Figure 2. Surface FADs installed with trawl ring.

\subsection{Pengukuran Parameter Lingkungan Habitat Nautilus Bercangkang Rapuh}

Pengukuran parameter perairan dilakukan untuk mengetahui lingkungan habitat Nautilus bercangkang rapuh di perairan teluk Tomini. Adapun parameter yang diukur dalam penelitian ini adalah suhu, salinitas 
dan kedalaman. Suhu diukur menggunakan termometer, salinitas air laut diukur menggunakan refraktometer. Pengukuran suhu dan salinitas dilakukan pada titik sampling pada lokasi Nautilus bercangkang rapuh ditemukan.

\subsection{Pengukuran dan Pengamatan Nautilus Bercangkang Rapuh}

Sampel yang berhasil dikumpulkan, diukur panjangnya menggunakan jangka sorong dengan tingkat ketelitian $0,05 \mathrm{~mm}$ dan diamati morfologinya. Ismail et al. (2013) menyatakan pengukuran panjang total Cephalopoda dilakukan dengan cara mengukur mulai dari ujung tentakel paling panjang sampai ke bagian paling belakang. Identifikasi morfolologi yang berdasarkan Taksonomi dan juga biologi Argonauta (Cephalopoda: Argonautidae) dengan material khusus Australia (Finn, 2013). Ada pun dimensi tubuh Nautilus bercangkang rapuh yang diukur meliputi: Panjang Mantel dorsal (PMd), diukur dari titik tengah mata hingga akhir posterior mantel. Panjang Mantel ventral (PMv), diukur dari batas anterior mantel pada garis tengah ventral hingga ujung mantel. Panjang Total (PT), diukur dari bagian ujung lengan terpanjang hingga akhir posterior mantel. Lebar Mantel (LM), dari mantel yang diukur pada bagian dorsal mantel. Lebar Kepala (LK), lebar terbesar dari kepala pada bagian permukaan yang terdapat mata. Diameter Mata (DM), diukur dari tonjolan mata (bulbus) ke bulbus sebelahnya. Panjang Sifon (PS), diukur dari bukaan anterior ke bagian posterior dan Lebar Lengan (LL), dari lengan pada titik tengah dari panjang.

\section{HASIL DAN PEMBAHASAN}

\subsection{Hasil}

Sampel yang tertangkap adalah Nautilus bercangkang karena memiliki cangkang rapuh dan transparan sehingga disebut Nautilus bercangkang rapuh. Nautilus bercangkang yang berhasil dikumpulkan pada bulan Maret hingga bulan Desember berjumlah 6 spesimen (Figure 3), dari 6 spesimen ditemukan 4 spesimen yang bertelur. Hasil pengukuran dapat dilihat pada Table 1. Hasil pengamatan menunjukkan bahwa biota yang ditemukan adalah genus Argonauta dengan ciri khas dari matanya yang besar dan memiliki 4 pasang tentakel dibagian kepalanya. Setiap tentakel terdapat 2 baris batil pengisap. Hasil identifikasi karakter morfologi cangkang ditemukan bahwa dari 6 spesimen yang tertangkap, 2 spesimen adalah jenis $A$. argo dan 4 spesimen adalah $A$. hians.

Figure 3, diperlihatkan bahwa hasil tangkapan paling banyak terjadi di bulan Desember yaitu sebanyak 3 spesimen jenis $A$. hians sedangkan di bulan Mei, Oktober dan November masing-masing hanya 1 spesimen. Pada bulan Mei dan November hasil tangkapan adalah jenis $A$. argo dan pada bulan Oktober adalah jenis $A$. hians.

Sampel Nautilus bercangkang rapuh

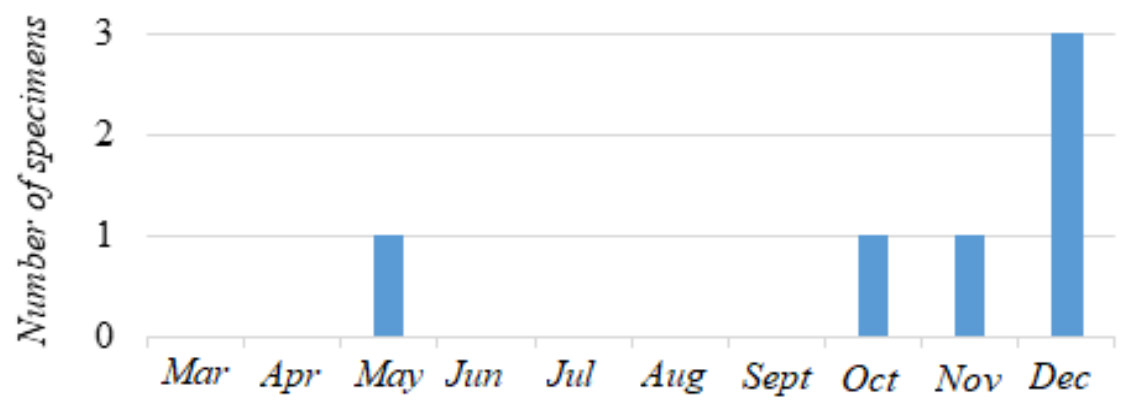

Mounth

Figure 3. Paper Nautilus caught from March until December. 
Nautilus Bercangkang Rapuh dari Teluk Tomini ...

Table 1. Result of morphometric character measurement of paper Nautilus.

\begin{tabular}{cccccccccc}
\hline \multirow{2}{*}{ Code } & \multicolumn{8}{c}{ Morphometrics $(\mathrm{mm})$} \\
\cline { 2 - 10 } & PT & PMd & PMv & LM & LK & DM & PS & LL & Egg \\
\hline PN1 & 64.8 & 18.1 & 15.3 & 10.0 & 8.2 & 7.0 & 7.0 & 2.0 & 0 \\
PN2 & 130.0 & 30.5 & 27.0 & 10.0 & 11.3 & 10.0 & 10.0 & 4.0 & 1 \\
PN3 & 65.0 & 18.8 & 15.5 & 10.1 & 8.4 & 8.0 & 7.1 & 2.0 & 1 \\
PN4 & 71.5 & 21.3 & 18.7 & 11.1 & 9.3 & 6.6 & 8.0 & 2.0 & 1 \\
PN5 & 80.8 & 19.0 & 14.3 & 13.0 & 10.5 & 7.0 & 9.0 & 3.0 & 1 \\
PN6 & 68.9 & 17.9 & 14.5 & 7.0 & 6.5 & 4.1 & 7.0 & 2.0 & 0 \\
\hline
\end{tabular}

Note: $0=$ No Egg, $1=E g g$

Table 2. Results of the paper Nautilus Shell Measurement.

\begin{tabular}{ccccccc}
\hline \multirow{2}{*}{ Sizes } & \multicolumn{7}{c}{ Code } \\
\cline { 2 - 7 } & PN1 & PN2 & PN3 & PN4 & PN5 & PN6 \\
\hline PN4 & 71.5 & 21.3 & 18.7 & 11.1 & 9.3 & 6.6 \\
PN5 & 80.8 & 19.0 & 14.3 & 13.0 & 10.5 & 7.0 \\
PN6 & 68.9 & 17.9 & 14.5 & 7.0 & 6.5 & 4.1 \\
\hline
\end{tabular}

(PN)1 dan PN3 adalah jenis A. argo dan sampel PN2, PN4, PN5 dan PN6 adalah jenis A. hians. Dari Table 1. memperlihatkan bahwa ukuran tubuh $A$. hians yang ditemukan umumnya lebih panjang dari A. argo. Pada PN2-PN5 ditemukan telur pada cangkangnya, dan pada ukuran PN1 dan PN6 ditemukan tanpa telur.

Pada Table 2 terlihat bahwa rata-rata panjang A. argo adalah $34,05 \mathrm{~mm}$ atau belum mencapai $50 \%$ dari ukuran maksimal-nya. Umumnya $A$. argo memiliki panjang cangkang $260 \mathrm{~mm}$ (Finn, 2013) dan rerata panjang A. hians yang ditemukan adalah 47,02 $\mathrm{mm}$ atau hampir mencapai $50 \%$ dari ukuran maksimalnya.

\subsubsection{Argonauta argo}

Pada Figure 4 terlihat bahwa organ tubuh terlindungi oleh cangkang. A. argo berwarna putih transparan sehingga organ tubuh tampak dari luar. Bagian dorsal cangkangnya tipis dan sempit, dengan ukuran yang sama dengan bentuk yang melengkung bulat pada dorsal dan konsisten. Bagian tubuh tidak melekat kuat pada cangkang seperti layaknya moluska, sehingga tubuhnya mudah keluar dari dalam cangkang. Cangkang sangat rapuh sehingga sangat mudah pecah. Saat ditemukan tentakel melingkar menutupi tubuh bagian dalam, diduga sebagai pertahanan terhadap predator.

$\begin{array}{ll}\text { Phylum } & \text { : Mollusca } \\ \text { Class } & \text { : Cephalopoda } \\ \text { Subclass } & \text { : Coleoidea } \\ \text { Ordo } & \text { : Octopodida } \\ \text { Family } & \text { : Argonautidae } \\ \text { Genus } & \text { : Argonauta } \\ \text { Spesies } & \text { : Argonauta argo Linnaeus, } 1786\end{array}$

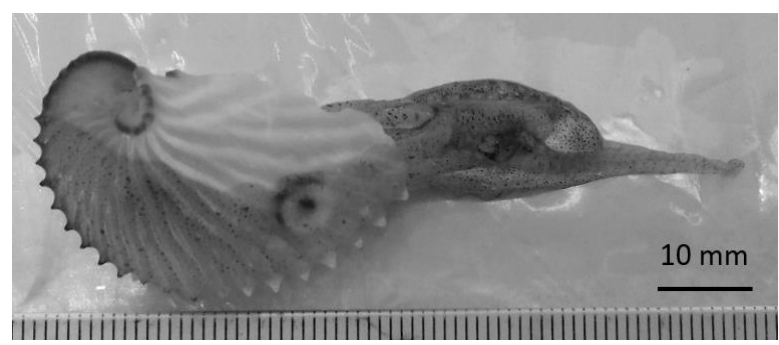

Figure 4. A. argo species Linnaeus, 1786 found on Tomini Bay.

Tubuh Argonauta sangat terlihat menyerupai gurita (Figure 5) memiliki mata yang besar pada kepalanya yang membulat kecil, terdapat 8 tentakel, 4 tentakelnya me- 
miliki ukuran lebih panjang dari 2 tentakel lainnya. Setiap tentakel terdapat 2 baris batil pengisap, batil hisap (sucker) berjumlah antara 12 sampai 13. Mantel panjang tipis dan berotot.

Ukuran mantel dorsal lebih besar dari mantel ventral (Figure 6). Warna kulit, otot daging, radula mirip seperti gurita dan berlendir banyak. Pada tengah-tengah tentakel terdapat radula yang dikelilingi oleh batil pengisap dan memiliki sifon atau corong pada bagian ventral dekat kepala.

Cangkang berbentuk pipih berwarna putih dan pada bagian lateral terdapat rusuk yang tersusun rapi sampai ke bagian dorsal.

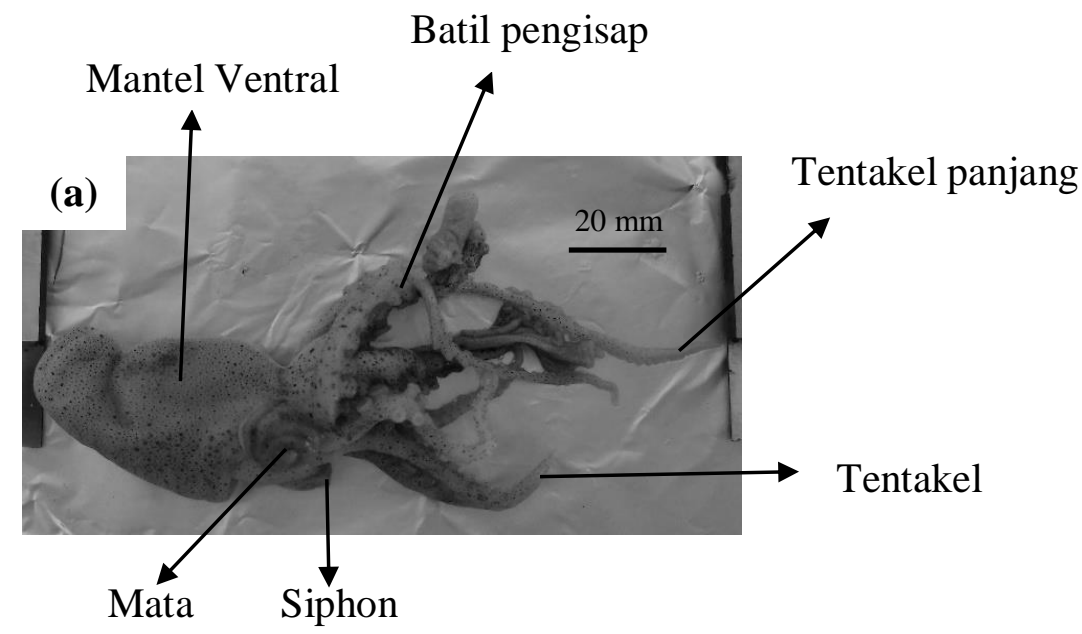

Figure 5. A. argo Body Parts (a) Radula sighting (b).

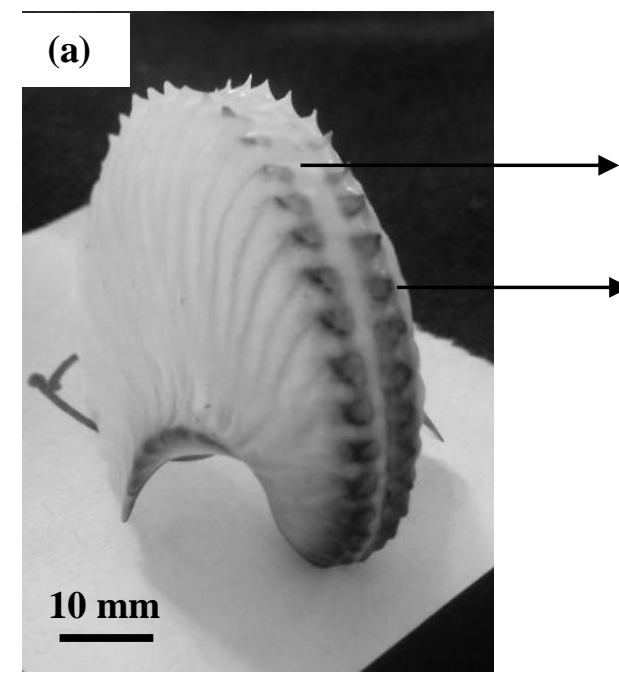

Dorsal view

Duri kecil runcing

Umbilikus
Di sepanjang sisi dorsal hingga umbikulus terdapat dua baris tonjolan kecil runcing yang berdekatan menyerupai duri-duri kecil yang tersusun sejajar dengan rusuk, sehingga jumlah rusuk dan duri sama. Permukaan lateral mulus dan tidak terdapat tonjolantonjolan kecil. Bagian dorsal hingga mendekati umbilikus berwarna coklat kehitaman. Sepanjang sisi ventral ujung tebal dan tampak seperti tanduk. Pada salah satu spesimen A. argo terdapat telur yang sangat kecil berwarna putih dan bergerombol. Sampel $A$. argo yang tertangkap memiliki ukuran rerata panjang cangkang $=34,05 \mathrm{~mm}$, lebar cangkang $=22,20 \mathrm{~mm}$ dan lebar aperture $=11,15 \mathrm{~mm}$.
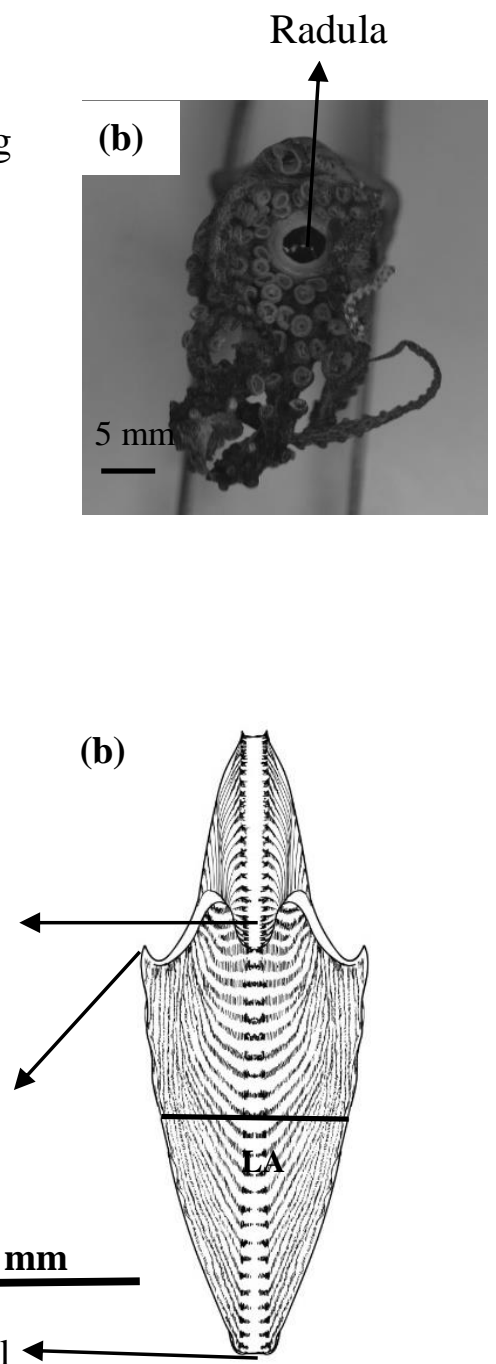

Figure 6. A.argo shell, ventral region (a) dorsal region (b). 


\subsubsection{Argonauta hians}

A. hians memiliki cangkang berwarna gelap berbeda dengan $A$. argo yang berwarna putih cerah (Figure 7) Warna kulit terlihat gelap menyerupai warna cangkang. Serupa seperti A. argo, daging tubuh tidak menyatu pada cangkang sehingga tubuhnya mudah dikeluarkan dari cangkang. Cangkang sangat rapuh dan mudah pecah. Pada saat ditemukan sama seperti $A$. argo tentakel panjang melingkari menutupi tubuh bagian dalam.

Bagian tubuh $A$. hians serupa dengan A. argo tetapi pada pada $A$. hians memiliki 2 tentakel lebih panjang dari 4 tentakel lainnya dan terdapat 2 baris sucker berjumlah 10-11 pada semua tentakelnya (Figure 8 ).

Nautilus bercangkang rapuh jenis $A$. hians terlihat bahwa aperturenya berbeda dengan A. Argo (Figure 9). Bila pada A. argo memanjang maka pada $A$. hians lebih melebar. Bagian aperture merupakan salah satu bagian yang membedakan masing-masing jenis Argonauta. Selain bagian aperture rusuk pada permukaan lateral dan tonjolan pada dorsal juga berbeda satu dengan yang lainnya.

Bentuk cangkang tipis, agak lebar tidak pipih seperti A. argo. A. hians memiliki cangkang berwarna gelap (Figure 10). Rusuk lateral halus, lebih tebal dan renggang serta tidak sejajar dengan tonjolan atau duri tumpul di bagian dorsal. Sehingga jumlah rusuk dan duri berbeda. Sepanjang sisi dorsal yang lebar terdapat dua baris tonjolan yang besar dan tumpul. Sepanjang sisi apertural melebar dan tidak membentuk seperti sayap. A. hians yang ditemukan memiliki rerata PC 47,02 mm, LC 33,07 mm dan LC 21,30 mm.

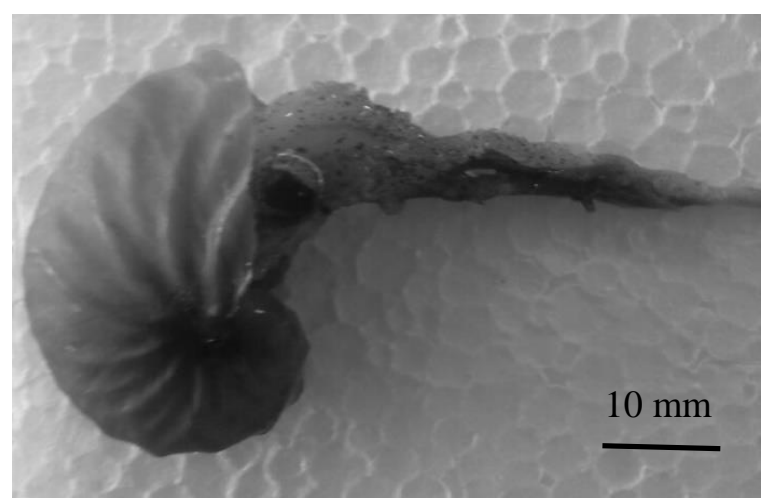

Figure 7. A. hians species Lightfoot, 1786.

\subsubsection{Parameter Lingkungan}

Hasil pengukuran suhu, salinitas dan kedalaman perairan habitat Nautilus bercangkang rapuh dapat dilihat pada Table 3 . Table 3 memperlihatkan bahwa Nautilus bercangkang rapuh digolongkan sebagai epipelagic karena mendiami perairan pada kedalaman kurang dari $200 \mathrm{~m}$.

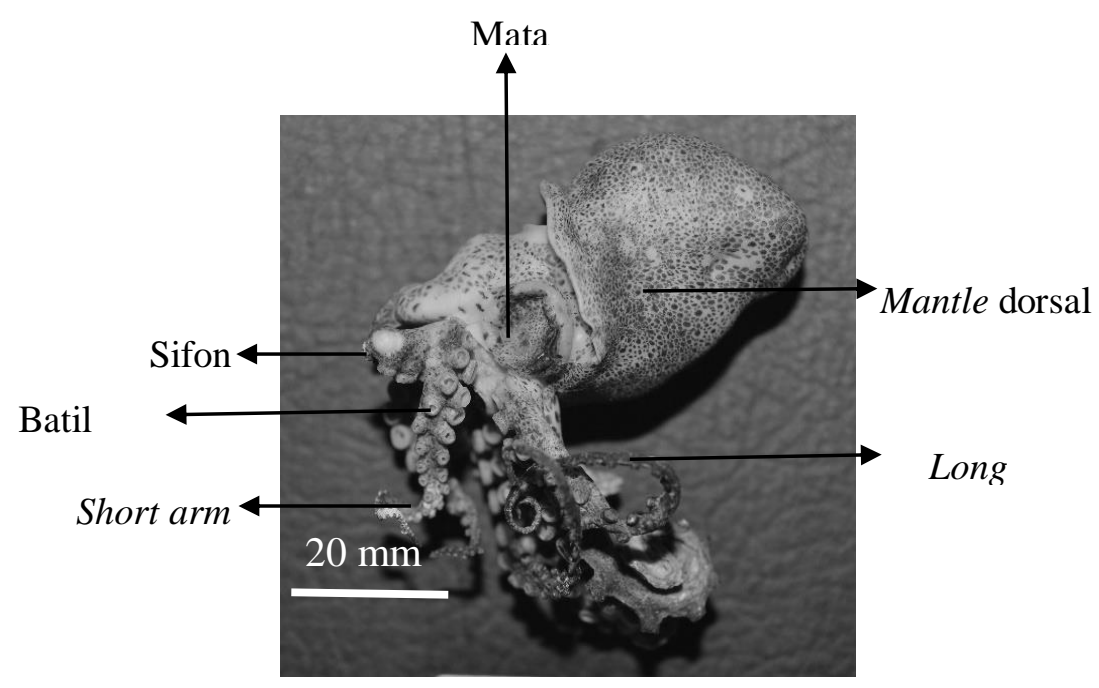

Figure 8. A. Hians Body Sighting Lightfoot, 1786. 


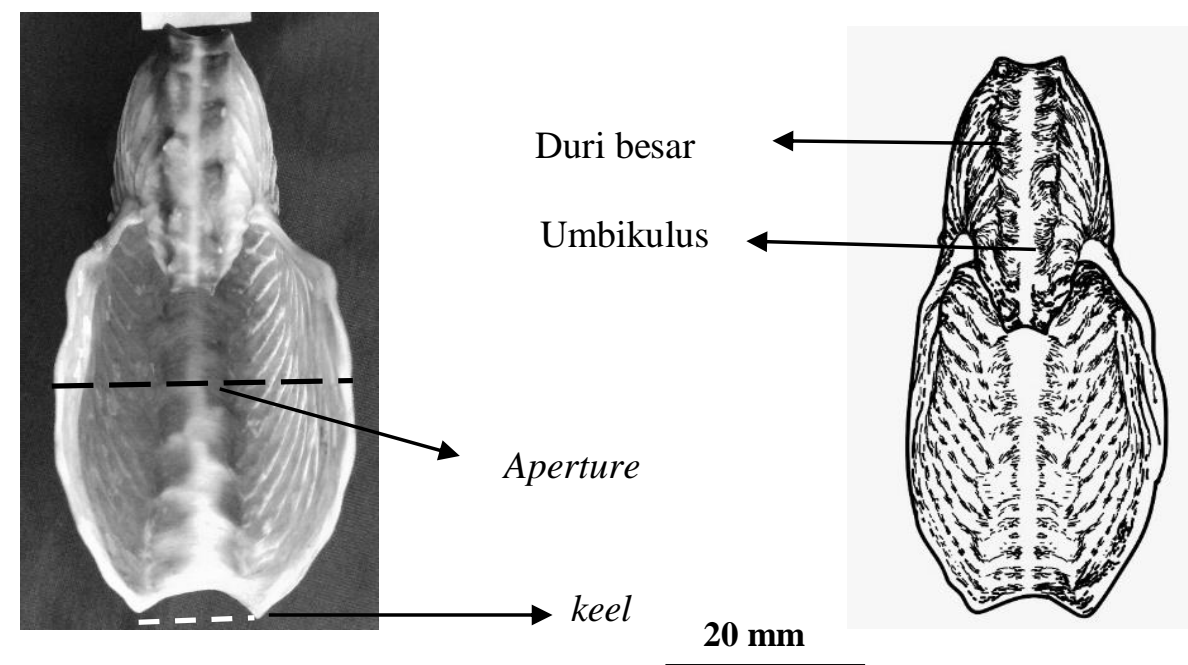

Figure 9. A. hians ventral shell sight, Tomini Bay.

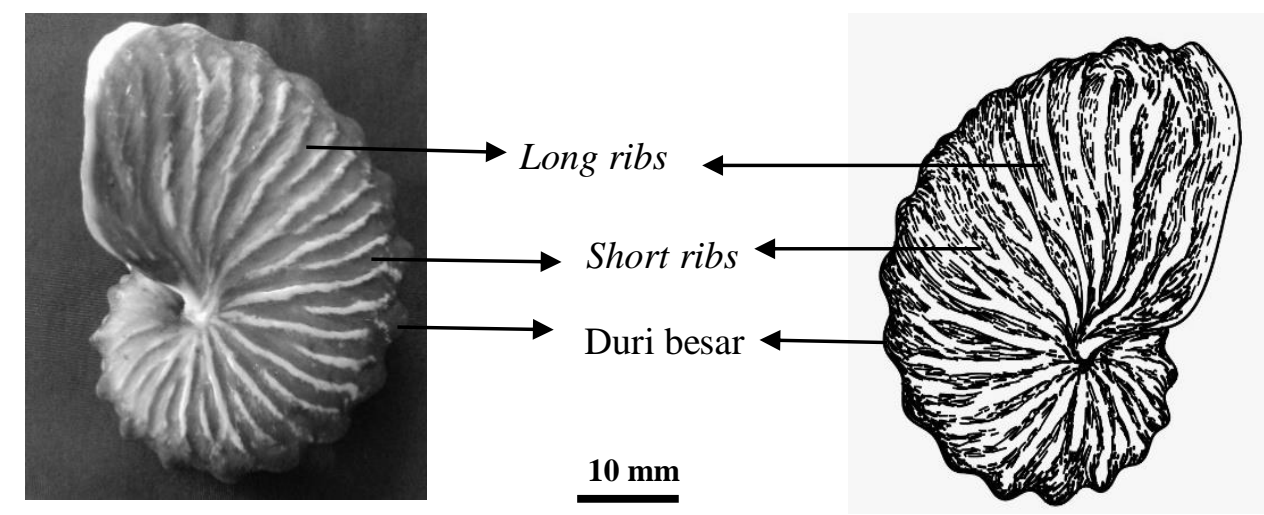

Figure 10. A. Hians lateral sight.

Table 3. Environmental parameters.

\begin{tabular}{cccc}
\hline \multirow{3}{*}{ Station } & \multicolumn{3}{c}{ Oceanography Variable } \\
\cline { 2 - 4 } & $\begin{array}{c}\text { Temp } \\
\left({ }^{\circ} \mathrm{C}\right)\end{array}$ & $\begin{array}{c}\text { Salinity } \\
(\mathrm{ppm})\end{array}$ & Depth $(\mathrm{m})$ \\
\hline ST 1 & 28.8 & 35 & 70 \\
ST 2 & 29.9 & 37 & 80 \\
\hline
\end{tabular}

\subsection{Pembahasan}

Argonauta, umumnya disebut paper Nautilus atau Nautilus bercangkang rapuh yang tersebar di perairan tropis dan subtropis seluruh dunia hingga kedalaman $1000 \mathrm{~m}$. Argonauta tampak seperti gurita tetapi memiliki cangkang layaknya moluska. Bila moluska memiliki cangkang keras tetapi pada biota ini memiliki cangkang yang mudah rapuh sehingga disebut Nautilus bercangkang rapuh.

Argonauta, terdiri dari berbagai jenis, namun kini sebagian besar jenis-jenisnya sudah punah. Hasil identifikasi fosil ditemukan terdapat 8 jenis fosil yang tersebar di seluruh dunia (Martill \& Barker, 2006). Mujiono (2009) menyatakan bahwa di dunia kini masih ditemukan 6 jenis Cephalopoda bercangkang rapuh atau suku Argonautidae, yaitu jenis A. argo, A. bottgeri, A. hians, A. nodosa, A. nouryi, A. pasifica. Diantara 6 jenis tersebut, ada 5 jenis yang di temukan di perairan Indonesia, yaitu jenis: A. argo, $A$. bottgeri, A. hians, A. nodosa, A. nouryi. Tetapi menurut (Jereb et al., 2014) jenis $A$. nodosa tidak dijumpai di perairan Indonesia, 
karena Nautilus bercangkang rapuh hanya hidup diperairan bagian selatan dunia yang berarti Nautilus bercangkang rapuh yang terdapat di Indonesia hanya Argonauta argo, A. bottgeri, A. hians, dan A. nouryi. Diduga dahulu jenis $A$. nodosa ditemukan di Indonesia, namun kini telah punah.

Hasil penelitian di Sulawesi Tengah tentang Nautilus bercangkang rapuh memperlihatkan bahwa dari bulan Maret sampai bulan Desember 2016 hanya ada 2 jenis Nautilus bercangkang rapuh yang tertangkap, yaitu $A$. argo dan $A$. hians. A. argo merupakan spesies terbesar dari genus Argonauta. Nautilus bercangkang rapuh memiliki 8 lengan, setiap lengan memiliki dua baris batil pengisap, jumlah pengisap pada setiap lengan berbeda tergantung spesiesnya (Sundaram \& Mane, 2018). A. argo dikenali dari bentuk cangkangnya yang mempunyai ciri saluran yang sempit dan sama pada rusuknya dimana jarak antara kedua sisinya hampir sama dan konsisten (Finn, 2013). A. argo memiliki tentakel dorsal yang lebih besar dan lebar dan sebarannya sangat luat hampir di seluruh perairan dunia (Jereb et al., 2014). A. argo tampak berbeda bila dibandingkan dengan $A$. nodosus karena tentakel ke-4 lebih panjang dari tentakel ke-2, sedangkan sebaliknya terjadi pada $A$. nodosus yaitu tentakel ke-2 lebih panjang dari tentakel ke-4. Struktur cangkang A. argo mirip dengan A. bottgeri. Tetapi dari warna cangkangnya, sangat berbeda karena cangkang A. argo lebih putih bersih sedang cangkang $A$. bottgeri berwarna lebih gelap dan kusam.

Nautilus bercangkang rapuh jenis $A$. hians memiliki, saluran cangkang yang lebar pada rusuknya dan sepasang tonjolantonjolan yang tumpul serta jaraknya lebih lebar. Nautilus bercangkang rapuh semakin sulit ditemukan. Selama 9 bulan penelitian hanya 6 spesimen yang berhasil dikumpulkan. Hal ini diduga karena populasinya yang semakin menurun sehingga menjadi langka dan hubungannya dengan kondisi lingkungan sebagai habitatnya. Pada bulan Desember adalah kondisi peralihan musim, yaitu dari musim panas menuju musim penghujan. Pada musim peralihan, hewan laut lebih aktif berenang ke permukaan untuk untuk mencari makan. (Guerra et al., 2002) menyatakan bahwa Argonauta akan sering muncul ke permukaan bila ada perubahan temperatur di permukaan air.

\section{KESIMPULAN}

Berdasarkan identifikasi secara deskripsi morfologi, diketahui bahwa jenis Nautilus bercangkang rapuh yang ditemukan di perairan Teluk Tomini Kabupaten Parigi Moutong, Sulawesi Tengah terdiri dari 2 jenis yaitu Argonauta argo dan Argonauta hians. Perbedaan keduanya terlihat jelas dari warna cangkangnya.

\section{UCAPAN TERIMA KASIH}

Terima kasih kepada DKP Kabupaten Parigi Moutong yang telah memberikan ijin kepada kami untuk melakukan penelitian di perairan Teluk Tomini. Kepada TNI AL Kabupaten Parigi Moutong serta masyarakat setempat yang telah membantu penulis dalam pengambilan sampel serta Lab. Oseanografi FPIK-UNDIP yang telah membantu peneliti selama pengamatan sampel di Laboratorium.

\section{DAFTAR PUSTAKA}

Dinas Kelautan dan Perikanan (DKP) Parigi Moutong. 2018. Potensi usaha dan peluang investasi kelautan dan perikanan Provinsi Sulawesi Tengah. Kementerian Kelautan dan Perikanan. Indonesia. 2-17 pp.

Guerra, A.F., Gonzalez, \& F. Rocha. 2002. Appearance of the common paper nautilus Argonauta argo related to the increase of the sea surface temperature in the north-eastern Atlantic. J. of the Marine Biological Association of the UK, 82(5): 855858. 
http://doi.org/10.1017/S00253154020 06240

Finn, J. 2013. Taxonomy and biology of the Argonauts (Cephalopoda: Argonautidae) with particular reference to Australian Material. $J$. Molluscan Research, 33(3): 143-222. http://doi.org/10.1080/13235818.201 3.824854

Finn, J.K. 2018. Recognising variability in the shells of argonauts (Cephalopoda: Argonautidae): the key to resolving the taxonomy of the family. $J$. Molluscan Research, 77(6): 63-104. http://doi.org/10.24199/j.mmv.2018.7 7.05

Ismail, T, Z.A. Muchlisin, N. Fadli, \& I. Setiawan. 2013. Kebiasaan makan dan komposisi makanan tiga spesies cumi (Loligo edulis, Sepioteuthis lessoniana dan Sepia officinalis) hasil tangkapan nelayan dari Perairan Pantai Utara Provinsi Aceh. J. DPIK, 2(2): 97-103.

https://doi.org/10.13170/depik.2.2.75 1

Jereb, P., C. Roper, \& M. Norman. 2014. Cephalopods of The World. FAO Species Catalogue for Fishery Purposes. Rome. 3: 228-236. http://www.fao.org/3/a-i3489e.pdf

Martill, D.M. \& M.J. Barker. 2006. A paper Nautilus (Octopoda, Argonauta) from the miocene pakhna formation of Cyprus. Paleontology, 49(5): 10351041.

https://doi.org/10.1111/j.14754983.2006.00578.x

Mujiono, N. 2009. Cephalopoda Bercangkang di Indonesia. Prosiding Seminar Nasional Moluska 2. "Moluska: Peluang Bisnis dan
Konservasi”. Bogor, 11-12 Februari 2009. 14-23 pp.

Obie, M., E. Soetarto, T. Sumarti, \& S. Saharuddin. 2014. Konflik Etnis di Pesisir Teluk Tomini: Tinjauan Sosio-Ekologi Politik. Al-Tahrir: J. Pemikiran Islam, 14: 295-318. http://doi.org/10.21154/altahrir.v14i2.75

Sarif, F.D. Pringgenies, A. Hartoko, \& M. Sibero. 2017. Kemunculan Paper Nautilus di perairan Teluk Tomini Kabupaten Parigi Moutong Provinsi Sulawesi Tengah. Prosiding Seminar Nasional Kelautan dan Perikanan III 2017 Universitas Trunojoyo Madura. Madura, 7 September 2017. 28-31 pp.

Sundaram, S. \& S. Mane. 2018. Record of brown paper nautilus Argonauta hians Lightfoot, 1786 off Mumbai, northwest coast of India. Int. J. of Life Sciences, 3(4): 392-394.

Strobbe, F., M.A. McPeek, M. De Block, \& R. Stoks. 2010. Fish predation selects for reduced foraging activity. Behav. Ecol. Sociobiol., 65(2011): 241-247. https://doi.org/10.1007/s00265-0101032-y

Wallace, C.C., G. Paulay, B.W. Hoeksema, D.R. Bellwood, P.A. Hutchings, P.H. Barber, M. Erdmann, \& J. Wolstenholme. 2000. Nature and origins of unique high diversity reef faunas in The Bay of Tominy, Central Sulawesi: The Ultimate "centre of diversity"?. Prosiding International Coral Reef Symposium, Bali, Indonesia, 23-27 Oktober 2000. 185$192 \mathrm{pp}$.

Received : 21 April 2020

Reviewed : 18 July 2020

Accepted : 22 August 2020 
